\title{
Current and Emerging Drugs in the Treatment of Anemia in Patients with Chronic Kidney Disease
}

\author{
Hongzhen Zhong, Wenshan Lin, Shujun Lin, Tianbiao Zhou \\ Department of Nephrology, the Second Affiliated Hospital, Shantou University Medical College, 515041, Shantou, China
}

Received, May 12, 2020; Revised, July 27, 2020; Accepted, July 28, 2020; Published, July 28, 2020.

\begin{abstract}
Anemia is a common complication of chronic kidney disease (CKD), and its prevalence has shown a tendency to increase in many countries. Anemia is associated with incident heart failure and increases mortality in CKD patients, garnering public attention. Here, we reviewed recent studies about CKD with anemia, and tried to summarize the risks and causes and new progress in the treatment of renal anemia. Among the risks and causes, calcium and phosphorus metabolism disorders should be pointed out along with common causes such as iron and erythropoietin deficiencies, hypoxia, inflammation and uremic toxins, and so on. The new anti-anemia treatments mainly include hematopoietic materials supplementation, erythropoietin-stimulating agents, calcium and phosphorus regulators and hypoxia-inducible factor prolyl hydroxylase inhibitors.
\end{abstract}

\section{INTRODUCTION}

Renal anemia is a common and significant complication of chronic kidney disease (CKD), and has a high prevalence in many countries [1-4]. The 2012 KDIGO Clinical Practice guidelines suggest that anemia be defined as a hemoglobin level less than 130 $\mathrm{g} / \mathrm{L}$ in males or $120 \mathrm{~g} / \mathrm{L}$ in females over 15 years old [5]. Renal anemia is not independently associated with the baseline cognitive function or a decline in CKD [6], but is strongly associated with a rapid decline in the estimated glomerular filtration rate (eGFR) [7]. It is also an independent risk factor for incident heart failure [8], and of all-cause mortality in CKD patients [9]. The recommended target level of hemoglobin is $115-130 \mathrm{~g} / \mathrm{L}$ in adult CKD patients [5]. However, treatments for anemia also carry risks.

In this review, we summarize the causes of anemia in patients with CKD (Figure 1) and recent therapeutic regimens, trying to provide useful information for nephrologists about current and emerging drugs in the treatment of renal anemia.

\section{RISKS AND CAUSES}

\section{Hematopoietic material deficiencies}

Blood loss tends to result in iron deficiency because of the edematous gastrointestinal tract and hemodialysis.

Iron deficiency is the most commonly encountered reversible cause of anemia or worsening anemia in CKD patients [10]. It is believed that transferrin saturation, serum hepcidin and plasma neutrophil gelatinase-associated lipocalin were associated with renal anemia [11, 12]. This hypothesis explains that Helicobacter pylori (HP) infection may influence iron stores, but no significant effect on iron deficiency anemia is observed in HD patients with or without HP infection [13].

In end-stage renal disease (ESRD) patients on maintenance dialysis, folate deficiency, which manifests as megalocytic anemia, occurs mainly because of inadequate intake, rather than dialysisrelated loss or increased requirements during recombinant human erythropoietin (rhEPO) treatment. Folic acid supplementation was found to benefit hyporesponsiveness to rhEPO in elderly HD patients with folic acid deficiency anemia [14].

\section{Calcium and phosphate abnormalities}

In advanced non-dialysis-dependent CKD (NDDCKD) patients, circulating levels of calcium and phosphorus are strongly associated with anemia [15], and not coincidentally, $25(\mathrm{OH}) \mathrm{D}_{3}$ has been reported to be correlated with ESRD [16]. Parathyroid hormone $(\mathrm{PTH})$ has a direct toxic effect on EPO, and beyond that, it can cause aggravation of anemia via myelofibrosis. Brancaccio et al found that erythrocyte hematocrit levels could be increased after parathyroid resection in uremic patients [17].

Corresponding Author: Tianbiao Zhou: Department of Nephrology, the Second Affiliated Hospital, Shantou University Medical College, 515041, Shantou, China; E-mail: zhoutb@aliyun.com 


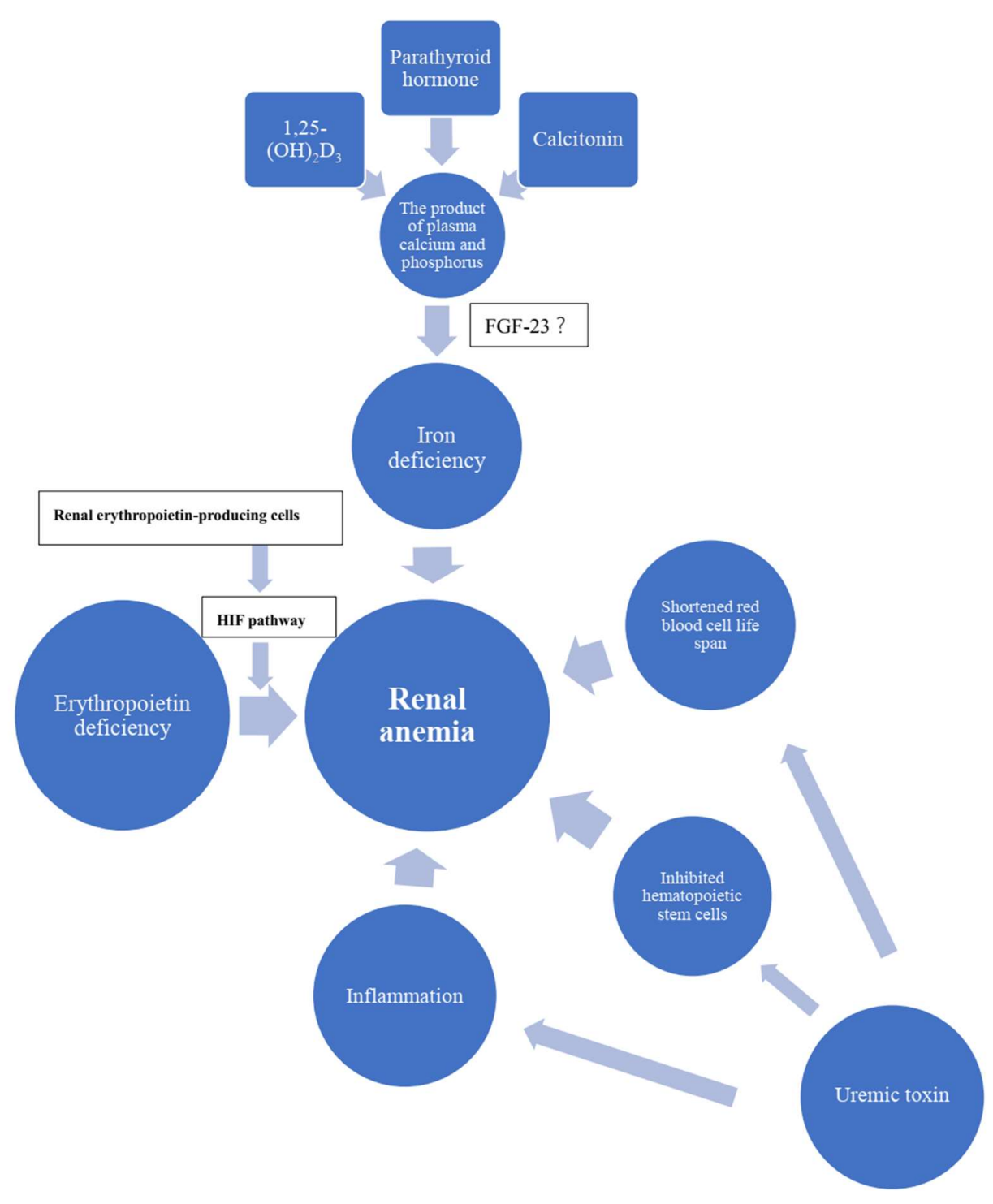

Figure 1. The potential causes of anemia in patients with chronic kidney disease

Phosphate plays a vital role in cellular energy metabolism, cell proliferation and nucleic acid synthesis. Calcium and phosphorus are absorbed in the intestinal tract and excreted by the intestine and kidney. Calcium phosphate is a component of bones, and is formed by coupling calcium and phosphorus in the body. Normally, the concentration of the product of plasma calcium and phosphorus is $35-40 \mathrm{mg} / 100 \mathrm{ml}$. When the product increases, bone formation is promoted, and calcium phosphate can even can be found in soft tissues, or specifically, in arteriosclerotic vascular diseases, when the product increases up to 70 $\mathrm{mg} / 100 \mathrm{ml}$. Conversely, the absorption of bones will be accelerated, calcification will be inhibited, and finally osteochondrosis will ultimately occur when the product is reduced. The product of calcium and phosphorus can be influenced by $1,25-(\mathrm{OH})_{2} \mathrm{D}_{3}, \mathrm{PTH}$, and calcitonin. $25-(\mathrm{OH}) \mathrm{D}_{3}$ is activated into $1,25-$ $(\mathrm{OH})_{2} \mathrm{D}_{3}$, and the latter can promote the absorption of calcium and phosphorus and inhibit the secretion of PTH, by $1 \alpha$ - hydroxylase in the kidney. PTH can stimulate the activation of $1,25-(\mathrm{OH})_{2} \mathrm{D}_{3}$, raise the calcium levels and promote phosphorus excretion, while calcitonin inhibits the activation of 1,25$(\mathrm{OH})_{2} \mathrm{D}_{3}$ and absorption of calcium and phosphorus. During ESRD, the kidney is severely damaged, 
resulting in a significant reduction in the level of 1,25 $(\mathrm{OH})_{2} \mathrm{D}_{3}$, unrecoverable abnormal concentrations of calcium and phosphorus and increased PTH levels, which leads to secondary hyperparathyroidism [18]. In a study among a large diverse population, higher serum phosphorus levels, which may influence hematopoiesis, should probably be blamed for anemia in early CKD or with normal kidney function [19]. Elevation of fibroblast growth factor 23 (FGF23), which is known as the major phosphate regulatory hormone, is also associated with a decline in hemoglobin over time and the development of anemia in CKD patients [20]. FGF23 levels are negatively related to hemoglobin levels during stage 3 or 4 of $\mathrm{CKD}$, which may be partially mediated through the effects of aldosterone [21].

Interestingly, FGF23 seems ambiguously related to iron deficiency. In renal transplant recipients, the levels of C-terminal FGF-23 have been found to be increased in the presence of iron deficiency, and the state of iron deficiency can promote the production and cleavage of intact FGF23 into C-terminal FGF23 [22]. There is reason to believe that iron deficiency may be involved in dysregulation of the intracellular FGF23-processing mechanism, but whether iron supplementation impacts the level of FGF23 is still controversial. A prospective study observed that oral ferric citrate hydrate could decrease serum intact FGF23 and C-terminal FGF23 levels and increase intact serum PTH levels, but with phosphate and $1,25(\mathrm{OH})_{2} \mathrm{D}$ were unchanged in HD patients [23]. Another study showed that iron supplementation failed to affect the intact and C-terminal FGF23 (i:cFGF23) ratios in CKD patients [24]. In NDD-CKD patients with normophosphatemia and ID, treatment with ferric citrate hydrate decreased PTH levels rather than serum FGF23 levels [25].

The reduction in $1,25-(\mathrm{OH})_{2} \mathrm{D}_{3}$ leads to a weakened inhibitory effect on aluminum deposition which can combine with phosphorus but at the same time, inhibit bone formation and bone mineralization, leading to aluminum-related bone disease [18]. Though there has been continuous improvement of hemodialysis systems and advances in phosphatebinding medications, aluminum toxicity, should be considered with daily supplies such as aluminum utensils for cooking in HD patients [26].

\section{Erythropoietin deficiency}

Erythropoietin deficiency is largely responsible for renal anemia. Under normal circumstances, renal erythropoietin-producing (REP) cells which act as sensors to increase EPO secretion by sensing the oxygen drop, are located in the marginal medullary area of the renal cortex. During the development of CKD, REP cells stop producing EPO, dedifferentiate and participate in renal fibrosis [27], and renal fibrosis will impact EPO production in turn.

\section{Hypoxia inducible factor (HIF) pathway}

HIFs regulate the gene expression to promote the body's adaptation to hypoxia, which is signal for angiogenesis, erythrogenesis and glycolysis [28], and specifically, the expression of the EPO gene in the kidney via the PHD2-HIF-2 $\alpha$ pathway [29]. Under hypoxic conditions, HIF-2 regulates EPO synthesis in the kidney and liver, thus stimulating erythrogenesis [30]. Characterized as fibroblasts, pericytes and neurons, REP cells may have correlative functions. It is premised that REP cells could function as neurons, integrating the information on blood oxygen concentration and local oxygen consumption from sensing tissue $\mathrm{pO}_{2}$, and thereby regulate EPO secretion [27]. Additionally, HIFs activate a set of genes involved in ferric absorption and transport, increasing the intestinal iron uptake, promoting iron transport to tissues, and downregulating hepcidin [31].

\section{Inflammation}

Anemia and inflammation are common in peritoneal dialysis (PD) patients, and anemia is suggested to correlate with inflammation in PD patients [32]. However, another study showed no association between blood cell life span and inflammatory biomarkers, such as interleukins-6,18, and 10 and high-sensitivity C-reactive protein [33].

\section{Uremic toxins}

Red blood cell life span is positively correlated with levels of uric acid and blood urea nitrogen [33] and CKD progression [34]. In CKD stage $3 / 4$ or HD patients, uremic toxins increase erythrophagocytosis by increasing eryptosis and promoting a proinflammatory monocyte phenotype [35]. In addition, the numbers of CD55- and CD59-deficient red blood cells are significantly higher in CKD patients than in controls [36], though the red blood cells are usually positive in paroxysmal nocturnal hemoglobinuria. As a natural inhibitor of pluripotent hematopoietic stem cell proliferation, $\mathrm{N}$-acetyl-serylaspartyl-lysyl-proline accumulates due to CKD, which ultimately leads to anemia [37]. Controversially, uremic toxin concentrations, such as indole 3-acetic acid, paracresyl sulfate and indoxyl sulfate, are 
detected, showing no association with anemia parameters in HD patients [38].

\section{Other causes and risks}

In addition to the abovementioned factors, an unavoidable cause of anemia is chronic blood loss, including hemorrhaging trends and blood residue in dialyzers during hemodialysis. A cohort study identified a number of independent risk factors for anemia, such as CKD stage, body mass index, smoking, leukocyte count, serum albumin, phosphorus concentration, calcium, and iron markers [39]. In addition, albuminuria is observed as one of the significant risk factors for eGFR [9], which is inextricably linked with renal anemia. In NDDCKD patients, blood manganese levels are positively associated with $\mathrm{Hb}$ levels as well [40]. Serum adiponectin, an adipokine secreted by adipocytes, is considered to be associated with anemia development in CKD. A higher serum adiponectin level is reported to be independently associated with a low hemoglobin level [41].

\section{TREATMENT}

While transfusion is not favorable, treatment with antianemia medications, although well accepted, nevertheless comes with risk in HD patients with anemia [42]. It is important to maintain stable antianemic drug concentrations for erythron response in dialysis patients and monitor the fluctuations in concentration, as the high variability of anti-anemic drugs will lead to a less successful erythron response [43]. Recent anti-anemia therapies are summarized as follows.

\section{Hematopoietic material supplementation therapy}

Oral iron supplementation via ferrous citrate iron is well-tolerated and efficient in IDA and CKD patients, regardless of NDD-CKD or hemodialysis-dependent CKD (HDD-CKD) [25, 44]. However, the optimal administration route and frequency of drug application are still being determined. It was reported that only $21.6 \%$ of anemic patients achieved an increase in $\mathrm{Hb}$ of at least $1 \mathrm{~g} / \mathrm{dL}$ via oral iron administration [45], while intravenous iron therapy may be an alternative for nonresponders using oral iron therapy [46]. Kalra et al hold the opinion that intravenous iron therapy is well tolerated and more efficacious than oral iron to increase $\mathrm{Hb}$ levels [47]. It is believed that intravenous iron therapy is not only effective and tolerated, but also helpful for lowering erythropoietin-stimulating agents (ESA) doses [48]. Ishida et al considered that intravenous iron can be administered for bacterial infection in HDD-CKD patients, although this treatment is deprecated by anemia guidelines for CKD [49]. In contrast, others think that risks of serious adverse events, including infectious diseases and cardiovascular events, are relatively increased in NDD-CKD patients on intravenous iron therapy [50]. The liver iron concentration was reported to be elevated during standard intravenous iron supplementation in HDD-CKD patients [51]. Concerning the issue of frequency of ESA application, intermittent intravenous iron administration is more highly recommended than continuous administration for stable antianemia efficacy in patients on maintenance hemodialysis [52]. Hepcidin is the key regulator of iron homeostasis. Hepcidin-25 was considered a significant predictor of erythrocytopoiesis response after intravenous iron therapy in CKD patients [53], while an RCT showed that neither the baseline level nor the change in hepcidin was able to predict response to iron therapy in NDD-CKD patients [54].

Folic acid and vitamin B12 deficiencies are important causes of anemia; however, supplementation with vitamins seems unessential for improving anemia but is associated with delaying the progression of CKD and reducing cardiovascular risks in CKD patients $[14,55,56]$.

\section{Calcium and phosphorus metabolism regulation}

Cinacalcet, a drug used in the treatment of hyperparathroidism secondary to CKD, suggests an additional benefit in the management of anemia in HDD-CKD patients [57] via PTH pathways [58]. Ironbased phosphate binders, represented by sucroferric oxyhydroxide and ferric citrate, are gradually emerging. In HDD-CKD patients who were receiving antihyperphosphatemic drugs with poor dephosphorizing effects, the administration of sucroferric oxyhydroxide had lower serum phosphorus and FGF-23 levels and a higher hemoglobin concentration compared to those without sucroferric oxyhydroxide treatment [59]. There were 441 patients on dialysis who were randomly assigned to two groups, with one group treated with ferric citrate and the other treated with sevelamer, calcium acetate or both. Over 52 weeks, no significant difference was seen in the mean serum phosphorus level, but increased mean hemoglobin levels and red blood cell mean cell volume were statistically significant in the ferric citrate group. Then, the ferric 
citrate group was sequentially rerandomized into two groups, a ferric citrate group and a placebo group. After 1 month of treatment, the ferric citrate group presented a lower mean serum phosphorus level than the placebo group. A conclusion was drawn that ferric citrate could decrease serum phosphorus as well as improve anemia [60]. In NDD-CKD patients, ferric citrate is also effective in reducing FGF23 and improving renal anemia [61]. Currently, sucroferric oxyhydroxide and ferric citrate have been approved for marketing in the United States.

\section{Erythropoietin stimulating agents (ESAs)}

ESAs may have renoprotective effects and slow the progression of CKD [62]. Long-acting ESAs tend to be more effective and stable than short-acting ESAs in treating anemia [63], and a fixed dose of long-acting ESAs at a higher frequency can improve appetite, reduce inflammation and correct anemia in patients on hemodialysis [64]. For predialysis patients with CKD, long-acting ESAs may be more useful, because of the lower frequency of hospital visits [65]. Darbepoetin, a newer ESA with a longer half-life than rhEPO, split into "mini-doses", or fixed small doses, and used at a frequency of twice-monthly or once a month is effective in CKD patients [66, 67]. Individualized dosing of ESAs through a computer-designed dosing system, can facilitate improvement in $\mathrm{Hb}$ levels, decrease $\mathrm{Hb}$ variability and reduce the dose of ESAs required to achieve target [68]. Subcutaneous epoetin is associated with a lower dose of ESAs and lower risks of death and hospitalization than intravenous administration in HD patients [69].

The $\mathrm{Hb}$ level usually fluctuates widely in ESAtreated HDD-CKD patients, which fortunately, has been reported to have no significant impact on mortality and hospitalization rates [70]. ESAs have similar anemic control in patients either with or without transplantation owing to chronic ESA rejection, though those with transplantation were supposed to have a more severe anemic state because of immunosuppression [71]. In a randomized, placebo-controlled trial with a 2-year follow-up, the renal function of patients with moderate CKD or with previous kidney transplantation was observed to be stable in the absence of low-dose ESAs, and early lowdose ESA therapy showed no significant effect on the amelioration of proteinuria [72]. Nakhoul et al reviewed the complicated and conflicting evidence on the treatment of renal anemia and held that ESAs should be individually prescribed according to the severity of anemia or stages of CKD to reduce the risk of cardiovascular events [73]. The initiation of ESA therapy is suggested when $\mathrm{Hb}$ levels decrease to $10-11 \mathrm{~g} / \mathrm{dL}$ in nondialysis CKD patients $[74,75]$.

The 2012 KDIGO clinical guidelines practice claims that the recommended target level of hemoglobin is $115-130 \mathrm{~g} / \mathrm{L}$ in adult CKD patients. Higher $\mathrm{Hb}$ levels have been found to be associated with higher mortality in CKD patients, and higher ESA doses are accompanied by a 1.2-1.5-fold increased risk of mortality [76]. A prospective cohort study showed that ESA hyporesponsiveness is associated with an increased risk of all-cause mortality in patients treated with HD [77]. ESA hyporesponsiveness may be related to the interaction between ESAs and statins [78], ACE gene polymorphism [79] and inhibition of erythropoietin receptor expression [80], which accounts for increasing doses of ESAs, and finally sets up a vicious circle of worsening responsiveness. Higher ESA doses resulted in higher mortality. Thus, the safety of high doses of ESAs has been questioned. An estimated EPO dose of $66.5 \mathrm{IU} / \mathrm{kg} / \mathrm{wk}$ was suggested for each $1 \mathrm{~g} / \mathrm{dL} \mathrm{Hb}$ level below the target, and the feasible maintenance dose was $8000 \mathrm{IU} /$ wk among HD patients [81]. Adequate dosages of iron preparations and ESA were suggested to be helpful in preventing cardio- and cerebrovascular events [82], and lower than normal doses (150 - 300IU) were more appropriate when $\mathrm{Hb}$ levels were greater than $11 \mathrm{~g} / \mathrm{dl}$ [83]. A study found that iron supplementation maintaining serum ferritin levels between 500 and $1200 \mathrm{ng} / \mathrm{ml}$ might help improve erythropoietin reactivity [84]. The standard dose remains inconclusive. V-J combinations of T-cell receptors have been reported to be helpful in predicting EPO responses in ESRD patients [85]. Erythropoietin-resistant anemia is associated with cardiovascular events in ESRD patients. As shown in a longitudinal study, inflammatory state, low serum iron reserve, continuous usage of ARBs and poor nutritional status are related risks in epoetin $\alpha$ resistance in HD patients [86]. Higher doses of rhEPO are required in ESRD patients with increased serum IL-17 and IFN- $\gamma$ levels [87]. C-reactive protein is a determining factor of ESA resistance in HD patients [88]. The platelet/lymphocyte ratio can be used as a predictive value in HD patients with erythropoietin resistance [89]. 


\section{Hypoxia inducible factor prolyl hydroxylase inhibitor (HIF-PHI)}

HIF-PHIs are an emerging drug class in the treatment of anemia with CKD. As a HIF stabilizer, HIF-PHIs simulate the hypoxic state of the body, increase endogenous EPO levels and coordinate iron utilization [90]. Vadadustat, roxadustat and daprodustat are representatives HIF-PHIs, and they have entered into clinical trials. All of them seem effective and safe, and have potential in the treatment of anemia with CKD in both NDD-CKD and HDD-CKD patients [91-99]. However, in our previous meta-analysis, HIF-PHIs were only effective in NDD-CKD patients [100]. Because of their connection with TGF- $\beta$ and VEGF, the issue of whether HIF-PHIs cause renal fibrosis remains unknown. HIF-PHIs are a topic of considerable interest in the treatment of renal anemia, but their safety and tolerability should be assessed cautiously [101, 102].

\section{Other treatments}

L-carnitine may help increase hemoglobin and reduce erythropoietin usage by its antioxidant and antiinflammatory effects [103]. Endoscopy is recommended for the early identification of gastrointestinal lesions, particularly adenomatous polyps and colorectal cancer, which may have an effect on anemia in CKD patients [104]. Excluding the disadvantage of albumin removal, a more permeable dialysis membrane is suggested for its potential impact on ESA resistance in HD patients [105]. Renal outcomes were independent of the patient/registered nurse ratio [106].

\section{CONCLUSION}

In conclusion, anemia is a common, mortality-related and increasing complication of CKD. CKD stage, body mass index, smoking, leukocyte count, serum albumin, phosphorus concentration, calcium, and low 25- $(\mathrm{OH}) \mathrm{D}_{3}$ and $1,25-(\mathrm{OH})_{2} \mathrm{D}_{3}$ levels are thought to be independent risk factors of renal anemia. Hematopoietic material deficiency, calcium and phosphorus metabolism disorder, EPO deficiency, hypoxia, inflammation and uremic toxins may be involved in the mechanism or progression of anemia in CKD. Correction of anemia conditions can lower mortality and hospital admission rates. Antianemia drugs mainly include hematopoietic material supplementation, ESAs, calcium and phosphorus regulators, and HIF-PHIs. However, much remains unknown and controversial. The treatment of renal anemia still has a long way to go.

\section{ACKNOWLEDGEMENTS AND CONFLICT OF INTEREST}

This study was supported by Guangdong Medical Science and Technology Research Fund Project (no. A2018336) and the Science and Technology Project of Shantou (Shanfuke [2019] 106: 190606165268433). Hongzhen Zhong and Wenshan Lin contributed equally to the preparation of this manuscript.

\section{REFERENCE}

1. Zaninetti C, Klersy C, Scavariello C, Bastia R, Balduini CL, Invernizzi R. Prevalence of anemia in hospitalized internal medicine patients: Correlations with comorbidities and length of hospital stay. Eur $J$ Intern Med. 2018;51:11-17. DOI: 10.1016/j.ejim.2017.11.001

2. Covic A, Jackson J, Hadfield A, Pike J, Siriopol D. Real-world impact of cardiovascular disease and anemia on quality of life and productivity in patients with non-dialysis-dependent chronic kidney disease. Adv Ther. 2017;34:1662-1672. DOI: 10.1007/s12325-017-0566-z

3. Ford D, Gilg J, Williams AJ. UK renal registry 19th annual report: Chapter 7 haemoglobin, ferritin and erythropoietin amongst UK adult dialysis patients in 2015: National and centre-specific analyses. Nephron. 2017;137 Suppl 1:165-188. DOI: 10.1159/000481369

4. Li Y, Shi H, Wang WM, Peng A, Jiang GR, Zhang JY, et al. Prevalence, awareness, and treatment of anemia in Chinese patients with nondialysis chronic kidney disease: First multicenter, cross-sectional study. Medicine. 2016;95(24):e3872. DOI: 10.1097/MD.0000000000003872

5. Group KDIGOAW. KDIGO clinical practice guideline for anemia in chronic kidney disease. Kidney Int Suppl. 2012;2(4):279-335.

6. Kurella Tamura M, Vittinghoff E, Yang J, Go AS, Seliger SL, Kusek JW, et al. Anemia and risk for cognitive decline in chronic kidney disease. $B M C$ Nephrol. 2016;17:13. DOI: 10.1186/s12882-0160226-6

7. Chang WX, Arai S, Tamura Y, Kumagai T, Ota T, Shibata S, et al. Time-dependent risk factors associated with the decline of estimated GFR in CKD patients. Clin Exp Nephrol. 2016;20:58-70. DOI: $10.1007 / \mathrm{s} 10157-015-1132-0$

8. He J, Shlipak M, Anderson A, Roy JA, Feldman HI, Kallem RR, et al. Risk factors for heart failure in patients with chronic kidney disease: The CRIC (chronic renal insufficiency cohort) study. $\mathrm{J} \mathrm{Am}$ Heart Asso. 2017;6(5) 6(5):e005336. DOI: 10.1161/JAHA.116.005336 
9. Han JS, Lee MJ, Park KS, Han SH, Yoo TH, Oh KH, et al. Albuminuria as a risk factor for anemia in chronic kidney disease: Result from the KoreaN cohort study for outcomes in patients with chronic kidney disease (KNOW-CKD). PloS One. 2015; 10:e0139747. DOI: 10.1371/journal.pone.0139747

10. Mircescu G, Garneata L, Capusa C, Ursea N. Intravenous iron supplementation for the treatment of anaemia in pre-dialyzed chronic renal failure patients. Nephrol Dial Transplant. 2006;21:120-124. DOI: $10.1093 /$ ndt/gfi087

11. Lee SW, Kim YH, Chung W, Park SK, Chae DW, Ahn C, et al. Serum hepcidin and iron indices affect anemia status differently according to the kidney function of non-dialysis chronic kidney disease patients: KoreaN cohort study for outcome in patients with chronic kidney disease (KNOW-CKD). Kidney Blood Press Res. 2017;42:1183-1192. DOI: $10.1159 / 000485865$

12. Kim IY, Kim JH, Lee DW, Lee SB, Rhee H, Song $\mathrm{SH}$, et al. Plasma neutrophil gelatinase-associated lipocalin is associated with iron status in anemic patients with pre-dialysis chronic kidney disease. Clin Exp Nephrol. 2018;22:28-34. DOI: 10.1007/s10157-017-1409-6

13. El-Said H, Attallah AHB, Ali-Eldin ZA. Does Helicobacter pylori infection play a role in iron deficiency anemia in hemodialysis patients? Clin Nephrol. 2017;88:177-180. DOI: $10.5414 / \mathrm{CN} 109034$

14. Schiffl H, Lang SM. Folic acid deficiency modifies the haematopoietic response to recombinant human erythropoietin in maintenance dialysis patients. Nephrol Dial Transplant. 2005;21:133-137. DOI: 10.1093/ndt/gfi086

15. Boronat M, Santana A, Bosch E, Lorenzo D, Riano M, Garcia-Canton C. Relationship between anemia and serum concentrations of calcium and phosphorus in advanced non-dialysis-dependent chronic kidney disease. Nephron. 2017;135:97-104. DOI: 10.1159/000450892

16. Kim YL, Kim H, Kwon YE, Ryu DR, Lee MJ, Park $\mathrm{KS}$, et al. Association between Vitamin D deficiency and anemia in patients with end-stage renal disease: A cross-sectional study. Yonsei $M$ ed J. 2016;57:1159-1164.

DOI: 10.3349/ymj.2016.57.5.1159

17. Brancaccio, D. Hyperparathyroidism and anemia in uremic subjects: A combined therapeutic approach. $J$ Am Soc Nephrol. 2004;15(S1): S21-4. DOI: 10.1097/01.asn.0000093369.09194.12

18. Huang W. Calcium phosphate metabolism and kidney regulates calcium phosphate balance. Chin J Blood Purif. 2004;3(4):175-177. DOI: 10.3969/j.issn.1671-4091.2004.04.001

19. Tran L, Batech M, Rhee CM, Streja E, Kalantar-
Zadeh K, Jacobsen SJ, et al. Serum phosphorus and association with anemia among a large diverse population with and without chronic kidney disease. Nephrol Dial Transplant. 2016;31(4):636-645. DOI: 10.1093/ndt/gfv297

20. Mehta R, Cai X, Hodakowski A, Lee J, Leonard M, Ricardo A, et al. Fibroblast growth factor 23 and anemia in the chronic renal insufficiency cohort study. Clin J Am Soc Nephrol. 2017;12(11):17951803. DOI: $10.2215 /$ CJN.03950417

21. Tsai MH, Leu JG, Fang YW, Liou HH. High fibroblast growth factor 23 levels associated with low hemoglobin levels in patients with chronic kidney disease stages 3 and 4 . Medicine. 2016;95(11):e3049.

DOI: 10.1097/MD.0000000000003049

22. Eisenga MF, van Londen M, Leaf DE, Nolte IM, Navis G, Bakker SJL, et al. C-terminal fibroblast growth factor 23, iron deficiency, and mortality in renal transplant recipients. $J$ Am Soc Nephrol. 2017;28(12):3639-3646.

DOI:

10.1681/ASN.2016121350

23. Iguchi A, Kazama JJ, Yamamoto S, Yoshita K, Watanabe $\mathrm{Y}$, Iino $\mathrm{N}$, et al. Administration of ferric citrate hydrate decreases circulating FGF23 levels independently of serum phosphate levels in hemodialysis patients with iron deficiency. Nephron. 2015;131(3):161-166. DOI: 10.1159/000440968

24. Tan SJ, Satake S, Smith ER, Toussaint ND, Hewitson TD, Holt SG. Parenteral iron polymaltose changes i:c-terminal FGF23 ratios in iron deficiency, but not in dialysis patients. Eur J Clin Nutr. 2017;71(2):180184. DOI: 10.1038/ejen.2016.217

25. Iguchi A, Yamamoto S, Yamazaki M, Tasaki K, Suzuki Y, Kazama JJ, et al. Effect of ferric citrate hydrate on FGF23 and PTH levels in patients with non-dialysis-dependent chronic kidney disease with normophosphatemia and iron deficiency. Clin Exp Nephrol. 2018;22:789-796. DOI: 10.1007/s10157017-1510-x

26. Bichu S, Tilve P, Kakde P, Jain P, Khurana S, Ukirade $\mathrm{V}$, et al. Relationship between the use of aluminium utensils for cooking meals and chronic aluminum toxicity in patients on maintenance hemodialysis: A case control study. $J$ Assoc Physicians India. 2019;67(4):52-56.

27. Nolan KA, Wenger RH. Source and microenvironmental regulation of erythropoietin in the kidney. Curr Opin Nephrol Hypertens. 2018;27:277-282.

DOI: 10.1097/MNH.0000000000000420

28. Schofield CJ, Ratcliffe PJ. Oxygen sensing by HIF hydroxylases. Nat Rev Mol Cell Biol. 2004;5:343354. DOI: $10.1038 / \mathrm{nrm} 1366$

29. Flamme I, Oehme F, Ellinghaus $P$, Jeske $M$, Keldenich Jr, Thuss U, et al. Mimicking hypoxia to treat anemia: HIF-stabilizer BAY 85-3934 
(Molidustat) stimulates erythropoietin production without hypertensive effects. PloS One. 2014;9:e111838.

DOI: 10.1371/journal.pone.0111838

30. Haase VH. Regulation of erythropoiesis by hypoxiainducible factors. Blood Rev. 2013;27(1):41-53. DOI: 10.1016/j.blre.2012.12.003

31. Gupta N, Wish JB. Hypoxia-inducible factor prolyl hydroxylase inhibitors: A potential new treatment for anemia in patients with CKD. Am J Kidney Dis. 2017;69(6):815-826.

DOI: 10.1053/j.ajkd.2016.12.011

32. Radic J, Basic-Jukic N, Vujicic B, Klaric D, Radulovic G, Jakic M, et al. Anemia is correlated with malnutrition and inflammation in croatian peritoneal dialysis patients: A multicenter nationwide study. Perit Dial Int. 2017;37(4):472-475. DOI:10.3747/pdi.2016.00013

33. Ma J, Dou Y, Zhang H, Thijssen S, Williams S, Kuntsevich V, et al. Correlation between inflammatory biomarkers and red blood cell life span in chronic hemodialysis patients. Blood Purif. 2017;43:200-205. DOI: 10.1159/000452728

34. Li JH, Luo JF, Jiang Y, Ma YJ, Ji YQ, Zhu GL, et al. Red Blood cell lifespan shortening in patients with early-stage chronic kidney disease. Kidney Blood Press Res. 2019;44:1158-1165. DOI: $10.1159 / 000502525$

35. Bonan NB, Steiner TM, Kuntsevich V, Virzi GM, Azevedo M, Nakao LS, et al. Uremic toxicityinduced eryptosis and monocyte modulation: The erythrophagocytosis as a novel pathway to renal anemia. Blood Purif. 2016;41:317-323. DOI: $10.1159 / 000443784$

36. Al-Faris L, Al-Humood S, Behbehani F, Sallam H. Altered expression pattern of CD55 and CD59 on red blood cells in anemia of chronic kidney disease. Med Princ Pract. 2017;26:516-522. DOI: 10.1159/000481823

37. Suzuki Y, Katagiri F, Sato F, Fujioka K, Sato Y, Fujioka T, et al. Clinical implications of plasma Nacetyl-seryl-aspartyl-lysyl-proline level in stable kidney transplant recipients. Clin Lab. 2016;62:1323-1328. DOI: 10.7754/Clin.Lab.2015.151136

38. Bataille S, Pelletier M, Sallee M, Berland Y, McKay $\mathrm{N}$, Duval A, et al. Indole 3-acetic acid, indoxyl sulfate and paracresyl-sulfate do not influence anemia parameters in hemodialysis patients. $B M C$ Nephrol. 2017;18:251. DOI: 10.1186/s12882-0170668-5

39. Ryu SR, Park SK, Jung JY, Kim YH, Oh YK, Yoo $\mathrm{TH}$, et al. The prevalence and management of anemia in chronic kidney disease patients: Result from the KoreaN cohort study for outcomes in patients with chronic kidney disease (KNOW-CKD). J Korean Med Sci. 2017;32(2):249-256. DOI: 10.3346/jkms.2017.32.2.249

40. Kim M, Koh ES, Chung S, Chang YS, Shin SJ. Altered metabolism of blood manganese is associated with low levels of hemoglobin in patients with chronic kidney disease. Nutrients. 2017;9(11):1177. DOI: 10.3390/nu9111177

41. Kim H, Yun HR, Park S, Jhee JH, Park JT, Yoo TH, et al. High serum adiponectin is associated with anemia development in chronic kidney disease: The results from the KNOW-CKD study. Cytokine. 2018;103:1-9. DOI: 10.1016/j.cyto.2017.12.018

42. Hauber B, Caloyeras J, Posner J, Brommage D, Tzivelekis S, Pollock A. Hemodialysis patients' preferences for the management of anemia. BMC nephrol. 2017;18(1):253. DOI: 10.1186/s12882-0170664-9

43. Lapina E, Batiushin M, Terentiev V, Gasanov M, Gasanova A. Clinical features of therapy of anemia and the significance of its fluctuation in the development of anemia in dialysis patients. Georgian Med News. 2017(272):64-69.

44. Sanai T, Ono T, Fukumitsu T. Beneficial effects of oral iron in Japanese patients on hemodialysis. Intern Med. 2017;56(18):2395-2399. DOI: 10.2169/internalmedicine.8520-16

45. Macdougall IC, Bock AH, Carrera F, Eckardt KU, Gaillard C, Wyck DV, et al. Erythropoietic response to oral iron in patients with nondialysis-dependent chronic kidney disease in the FIND-CKD trial. Clin Nephrol. 2017;88(12):301-310. DOI: 10.5414/CN109198

46. Takasawa K, Takaeda C, Wada T, Ueda N. Optimal serum ferritin levels for iron deficiency anemia during oral iron therapy (OIT) in Japanese hemodialysis patients with minor inflammation and benefit of intravenous iron therapy for OITnonresponders. Nutrients. 2018;10(4):428. DOI: 10.3390/nu10040428

47. Kalra PA, Bhandari S, Saxena S, Agarwal D, Wirtz G, Kletzmayr J, et al. A randomized trial of iron isomaltoside 1000 versus oral iron in non-dialysisdependent chronic kidney disease patients with anaemia. Nephrol Dial Transplant. 2016;31(4):646655. DOI: $10.1093 /$ ndt/gfv293

48. Biggar P, Leistikow F, Walper A. A prospective observational study of effectiveness and safety of iron isomaltoside in patients with chronic renal failure and iron deficiency anemia. Clin Nephrol. 2016;86 (2016)(12):310-318. DOI: $10.5414 / \mathrm{CN} 108941$

49. Ishida JH, Marafino BJ, McCulloch CE, Dalrymple LS, Dudley RA, Grimes BA, et al. Receipt of intravenous iron and clinical outcomes among hemodialysis patients hospitalized for infection. Clin $J$ Am Soc Nephrol. 2015;10(10):1799-1805. DOI: 10.2215/CJN.01090115

50. Agarwal R, Kusek JW, Pappas MK. A randomized 
trial of intravenous and oral iron in chronic kidney disease. Kidney Int. 2015;88(4):905-914. DOI: 10.1038/ki.2015.163

51. Holman R, Olynyk JK, Kulkarni H, Ferrari P. Characterization of hepatic and cardiac iron deposition during standard treatment of anaemia in haemodialysis. Nephrology (Carlton). 2017;22(2):114-117. DOI: 10.1111/nep.12735

52. Wan L, Zhang D. Effect of frequency of intravenous iron administration on hemoglobin variability in maintenance hemodialysis patients. Int Urol Nephrol. 2018;50(8):1511-1518. DOI: 10.1007/s11255-0181916-8

53. Drakou A, Margeli A, Theodorakopoulou S, Agrogiannis I, Poziopoulos C, Papassotiriou I, et al. Assessment of serum bioactive hepcidin-25, soluble transferrin receptor and their ratio in predialysis patients: Correlation with the response to intravenous ferric carboxymaltose. Blood Cells $\mathrm{Mol}$ Dis. 2016;59:100-105. DOI: 10.1016/j.bcmd.2016.05.006

54. Gaillard CA, Bock AH, Carrera F, Eckardt KU, Van Wyck DB, Bansal SS, et al. Hepcidin response to iron therapy in patients with non-dialysis dependent CKD: An analysis of the FIND-CKD Trial. PloS One. 2016;11(6):e0157063.

DOI:

10.1371/journal.pone.0157063

55. Capelli I, Cianciolo G, Gasperoni L, Zappulo F, Tondolo F, Cappuccilli M, et al. Folic acid and vitamin $\mathrm{B} 12$ administration in $\mathrm{CKD}$, why not? Nutrients. $\quad 2019 ; 11 \quad$ (2):383. DOI: 10.3390/nu11020383

56. Li Y, Spence JD, Wang X, Huo Y, Xu X, Qin X. Effect of Vitamin B12 Levels on the association between folic acid treatment and CKD progression: A post hoc analysis of a folic acid interventional trial. Am J Kidney Dis. 2020;75(3):325-332. DOI: 10.1053/j.ajkd.2019.07.020

57. Torun D, Yildiz I, Micozkadioglu H, Nursal GN, Yigit F, Ozelsancak R. The effects of cinacalcet treatment on bone mineral metabolism, anemia parameters, left ventricular mass index and parathyroid gland volume in hemodialysis patients with severe secondary hyperparathyroidism. Saudi J Kidney Dis Transpl. 2016;27(1):15-22. DOI: 10.4103/1319-2442.174053

58. Tanaka M, Yoshida K, Fukuma S, Ito K, Matsushita $\mathrm{K}$, Fukagawa $\mathrm{M}$, et al. Effects of secondary hyperparathyroidism treatment on improvement in anemia: Results from the MBD-5D study. PloS One. 2016;11(10):e0164865.

DOI: 10.1371/journal.pone.0164865

59. Shima H, Miya K, Okada K, Minakuchi J, Kawashima S. Sucroferric oxyhydroxide decreases serum phosphorus level and fibroblast growth factor 23 and improves renal anemia in hemodialysis patients. BMC Res Notes. 2018;11(1):363. DOI: 10.1186/s13104-018-3483-6

60. Lewis JB, Sika M, Koury MJ, Chuang P, Schulman G, Smith MT, et al. Ferric citrate controls phosphorus and delivers iron in patients on dialysis. J Am Soc Nephrol. 2015;26(2):493-503. DOI: 10.1681/ASN.2014020212

61. Block GA, Fishbane S, Rodriguez M, Smits G, Shemesh S, Pergola PE, et al. A 12-week, doubleblind, placebo-controlled trial of ferric citrate for the treatment of iron deficiency anemia and reduction of serum phosphate in patients with CKD Stages 3-5. Am J Kidney Dis. 2015;65(5):728-736. DOI: 10.1053/j.ajkd.2014.10.014

62. Tsuruya K, Yoshida H, Suehiro T, Fujisaki K, Masutani K, Kitazono T. Erythropoiesis-stimulating agent slows the progression of chronic kidney disease: a possibility of a direct action of erythropoietin. Ren Fail. 2016;38(3):390-396. DOI: 10.3109/0886022X.2015.1136874

63. Io H, Aizawa M, Funabiki K, Horikoshi S, Tomino Y. Impact of anaemia treatment for left ventricular remodelling prior to initiation of dialysis in chronic kidney disease patients: Efficacy and stability of long acting erythropoietin stimulating agents. Nephrology (Carlton). 2015;20(S4):7-13. DOI: 10.1111/nep. 12640

64. Liu WS, Chu DC, Chan HL, Li SY, Liu CK, Yang $\mathrm{CY}$, et al. Fixed dose of long-acting erythropoietic stimulating agents at higher frequency improves appetite, reduces inflammation and corrects anaemia in patients on haemodialysis. Clin Exp Pharmacol Physiol. 2016;43(10):875-882. DOI: 10.1111/14401681.12618

65. Kawahara K, Minakuchi J, Yokota N, Suekane H, Tsuchida K, Kawashima S. Treatment of renal anaemia with erythropoiesis-stimulating agents in predialysis chronic kidney disease patients: Haemoglobin profile during the 6 months before initiation of dialysis. Nephrology (Carlton). 2015;20(S4):29-32. DOI: 10.1111/nep.12647

66. Mendes M, Ferreira AC, Navarro D, Pinto B, Gomes F, Matias P, et al. Optimizing the use of darbepoetinalpha with a split strategy: A concept change. Clin Nephrol. 2018;89(2):113-119. DOI: 10.5414/CN109150

67. Al Raisi F, Al Salmi I, Kamble P, Al Shehri M, Shaheen FA. Initiation of darbepoetin for management of anemia in non-dialysis-dependent patients with chronic kidney disease. Saudi J Kidney Dis Transpl. 2016;27(6):1182-1187. DOI: 10.4103/1319-2442.194607

68. Gaweda AE, Jacobs AA, Aronoff GR, Brier ME. Individualized anemia management in a dialysis facility - long-term utility as a single-center quality improvement experience. Clin Nephrol. 2018;90(4):276-285. DOI: 10.5414/CN109499

69. Wright DG, Wright EC, Narva AS, Noguchi CT, 
Eggers PW. Association of erythropoietin dose and route of administration with clinical outcomes for patients on hemodialysis in the United States. Clin J Am Soc Nephrol. 2015;10(10):1822-1830. DOI: 10.2215/CJN.01590215

70. Thanakitcharu P, Jirajan B. Prevalence of hemoglobin cycling and its clinical impact on outcomes in Thai end-stage renal disease patients treated with hemodialysis and erythropoiesisstimulating agent. $J$ Med Assoc Thai. 2016;99(S2):S28-37.

71. Yamazaki K, Sakai K, Ohashi Y, Nihei H, Itabashi T, Muramatsu M, et al. Similar anemic control between chronic kidney diseases in patients with and without transplantation on entry to dialysis. Transplant Proc. 2017;49(1):57-60.

DOI:

10.1016/j.transproceed.2016.11.021

72. Fliser D, Dellanna F, Koch M, Wiggenhauser A. Early low-dose erythropoiesis-stimulating agent therapy and progression of moderate chronic kidney disease: a randomized, placebo-controlled trial. Nephrol Dial Transplant.2017;32(2):279-287. DOI: 10.1093/ndt/gfw418

73. Nakhoul G, Simon JF. Anemia of chronic kidney disease: Treat it, but not too aggressively. Cleve Clin $J \quad$ Med. 2016;83(8):613-624. DOI: 10.3949/ccjm.83a.15065

74. Akizawa T, Tsubakihara Y, Hirakata H, Watanabe Y, Hase H, Nishi S, et al. A prospective observational study of early intervention with erythropoietin therapy and renal survival in non-dialysis chronic kidney disease patients with anemia: JET-STREAM Study. Clin Exp Nephrol. 2016;20(6):885-895. DOI: 10.1007/s10157-015-1225-9

75. Evans M, Carrero JJ, Bellocco R, Barany P, Qureshi AR, Seeberger A, et al. Initiation of erythropoiesisstimulating agents and outcomes: a nationwide observational cohort study in anaemic chronic kidney disease patients. Nephrol Dial Transplant. 2017;32(11):1892-1901. DOI: 10.1093/ndt/gfw328

76. Suttorp MM, Hoekstra T, Mittelman M, Ott I, Krediet RT, Dekker FW, et al. Treatment with high dose of erythropoiesis-stimulating agents and mortality: analysis with a sequential Cox approach and a marginal structural model. Pharmacoepidemiol Drug Saf. 2015;24(10):10681075. DOI: $10.1002 /$ pds.3855

77. Bae MN, Kim SH, Kim YO, Jin DC, Song HC, Choi EJ, et al. Association of erythropoietin-stimulating agent responsiveness with mortality in hemodialysis and peritoneal dialysis patients. PloS One. 2015;10(11):e0143348.

DOI: 10.1371/journal.pone. 0143348

78. Hasegawa T, Zhao J, Fuller DS, Bieber B, Zee J, Morgenstern $\mathrm{H}$, et al. Erythropoietin hyporesponsiveness in dialysis patients: possible role of statins. Am J Nephrol. 2017;46(1):11-17. DOI:

\section{$10.1159 / 000477217$}

79. Nand N, Deshmukh AR, Joshi S, Sachdeva MP, Sakthivel. Role of ACE and IL-1beta gene polymorphisms in erythropoeitin hyporesponsive patients with chronic kidney disease with anemia. $J$ Assoc Physicians India. 2017;65(2):32-36.

80. Yokoro M, Nakayama Y, Yamagishi SI, Ando R, Sugiyama $\mathrm{M}$, Ito $\mathrm{S}$, et al. Asymmetric dimethylarginine contributes to the impaired response to erythropoietin in CKD-anemia. J Am Soc Nephrol. 2017;28(9):2670-2680. DOI: 10.1681/ASN.2016111184

81. Nafar M, Samavat S, Khoshdel A, Alipour-Abedi B. Anemia evaluation and erythropoietin dose requirement among hemodialysis patients: A multicenter study. Iran J Kidney Dis. 2017;11(1):5665.

82. Kataoka H, Tsuchiya K, Naganuma T, Okazaki M, Komatsu M, Kimura T, et al. Relationship between anaemia management at haemodialysis initiation and patient prognosis. Nephrology (Carlton). 2015;20(S4):14-21. DOI: 10.1111/nep.12639

83. Srinivasan R, Fredy IC, Chandrashekar S, Saravanan J, Mohanta GP, Manna PK. Assessment of erythropoietin for treatment of anemia in chronic kidney failure- ESRD patients. Biomed Pharmacother. 2016;82:44-48. DOI: 10.1016/j.biopha.2016.04.041

84. Hu JP, Cheng X, Xu XF, Yu GJ, Luo F, Zhang GS, et al. Reactivity of patients with maintenance hemodialysis to erythropoietin in the treatment of renal anemia. $J$ Biol Regul Homeost Agents. 2016;30(2):535-540.

85. Wong HS, Chang CM, Kao CC, Hsu YW, Liu X, Chang WC, et al. V-J combinations of T-cell receptor predict responses to erythropoietin in end-stage renal disease patients. J Biomed Sci. 2017;24(1):43. DOI: 10.1186/s12929-017-0349-5

86. Santos EJF, Hortegal EV, Serra HO, Lages JS, Salgado-Filho N, Dos Santos AM. Epoetin alfa resistance in hemodialysis patients with chronic kidney disease: a longitudinal study. Braz J Med Biol Res. 2018;51(7):e7288. DOI: 10.1590/1414$431 \times 20187288$

87. de Oliveira WV, Jr., de Figueiredo RC, de Paula AS, Turani SD, Velloso MSS, Pinheiro MB, et al. Study of association between interleukin-17 and interferongamma and recombinant human erythropoietin dose in patients undergoing peritoneal dialysis. Cytokine. 2017;96:24-29. DOI: 10.1016/j.cyto.2017.02.019

88. Yilmaz I, Ozkok A, Kostek O, Kolukisa A, Duran I, Odabas AR, et al. C-reactive protein but not hepcidin, NGAL and transferrin determines the ESA resistance in hemodialysis patients. Ren Fail. 2016;38(1):89-95. DOI: 10.3109/0886022X.2015.1106896

89. Taymez DG, Ucar E, Turkmen K, Ucar R, Afsar B, Gaipov A, et al. The predictive value of 
platelet/lymphocyte ratio in hemodialysis patients with erythropoietin resistance. Ther Apher Dial. 2016;20(2):118-121. DOI: $10.1111 / 1744-$ 9987.12380

90. Muchnik E, Kaplan J. HIF prolyl hydroxylase inhibitors for anemia. Expert Opin Investig Drugs. 2011;20(5):645-656.

DOI: $10.1517 / 13543784.2011 .566861$

91. Martin ER, Smith MT, Maroni BJ, Zuraw QC, deGoma EM. Clinical trial of vadadustat in patients with anemia secondary to stage 3 or 4 chronic kidney disease. Am J Nephrol. 2017;45(5):380-388. DOI: 10.1159/000464476

92. Chen N, Qian J, Chen J, Yu X, Mei C, Hao C, et al. Phase 2 studies of oral hypoxia-inducible factor prolyl hydroxylase inhibitor FG-4592 for treatment of anemia in China. Nephrol Dial Transplant. 2017;32(8):1373-1386. DOI: 10.1093/ndt/gfx011

93. Akizawa T, Tsubakihara Y, Nangaku M, Endo Y, Nakajima H, Kohno T, et al. Effects of daprodustat, a novel hypoxia-inducible factor prolyl hydroxylase inhibitor on anemia management in Japanese hemodialysis subjects. Am $J$ Nephrol. 2017;45(2):127-135. DOI: 10.1159/000454818

94. Provenzano R, Besarab A, Wright S, Dua S, Zeig S, Nguyen P, et al. Roxadustat (FG-4592) versus epoetin alfa for anemia in patients receiving maintenance hemodialysis: A phase 2, randomized, 6- to 19-week, open-label, active-comparator, doseranging, safety and exploratory efficacy study. $A m \mathrm{~J}$ Kidney Dis. 2016;67(6):912-924. DOI: 10.1053/j.ajkd.2015.12.020

95. Provenzano R, Besarab A, Sun CH, Diamond SA, Durham JH, Cangiano JL, et al. Oral hypoxiainducible factor prolyl hydroxylase inhibitor roxadustat (FG-4592) for the treatment of anemia in patients with CKD. Clin J Am Soc Nephrol. 2016;11(6):982-991. DOI: 10.2215/CJN.06890615

96. Pergola PE, Spinowitz BS, Hartman CS, Maroni BJ, Haase VH. Vadadustat, a novel oral HIF stabilizer, provides effective anemia treatment in nondialysisdependent chronic kidney disease. Kidney Int. 2016;90(5):1115-1122. DOI: 10.1016/j.kint.2016.07.019

97. Holdstock L, Meadowcroft AM, Maier R, Johnson BM, Jones D, Rastogi A, et al. Four-Week Studies of Oral Hypoxia-inducible factor-prolyl hydroxylase inhibitor GSK1278863 for treatment of anemia. $\mathrm{J} \mathrm{Am}$ Soc Nephrol. 2016;27(4):1234-1244. DOI: 10.1681/ASN.2014111139
98. Brigandi RA, Johnson B, Oei C, Westerman M, Olbina G, de Zoysa J, et al. A novel hypoxiainducible factor-prolyl hydroxylase inhibitor (GSK1278863) for anemia in CKD: a 28-day, phase 2A randomized trial. Am $J$ Kidney Dis. 2016;67(6):861-871. DOI: 10.1053/j.ajkd.2015.11.021

99. Besarab A, Provenzano R, Hertel J, Zabaneh R, Klaus SJ, Lee $\mathrm{T}$, et al. Randomized placebocontrolled dose-ranging and pharmacodynamics study of roxadustat (FG-4592) to treat anemia in nondialysis-dependent chronic kidney disease (NDD-CKD) patients. Nephrol Dial Transplant. 2015;30(10):1665-1673. DOI: 10.1093/ndt/gfv302

100. Zhong H, Zhou T, Li H, Zhong Z. The role of hypoxia-inducible factor stabilizers in the treatment of anemia in patients with chronic kidney disease. Drug Des Devel Ther. 2018;12:3003-3011. DOI: 10.2147/DDDT.S175887

101. Karuppagounder SS, Ratan RR. Hypoxia-inducible factor prolyl hydroxylase inhibition: robust new target or another big bust for stroke therapeutics? $J$ Cereb Blood Flow Metab. 2012; 32(7):1347-1361. DOI: $10.1038 /$ jcbfm.2012.28

102. Kaplan JM, Sharma N, Dikdan S. Hypoxia-inducible factor and its role in the management of anemia in chronic kidney disease. Int $J$ Mol Sci. 2018;19(2):389. DOI: 10.3390/ijms19020389

103. Emami Naini A, Moradi M, Mortazavi M, Amini Harandi A, Hadizadeh M, Shirani F, et al. Effects of oral L-carnitine supplementation on lipid profile, anemia, and quality of life in chronic renal disease patients under hemodialysis: a randomized, doubleblinded, placebo-controlled trial. J Nutr Metab. 2012;2012:510483. DOI: 10.1155/2012/510483

104. Garcia Agudo R, Aoufi Rabih S, Gonzalez Carro P, Perez Roldan F, Proy Vega B, Arias Arias A, et al. Gastrointestinal lesions in chronic kidney disease patients with anaemia. Nefrologia. 2019;39(1):50-57. DOI: $10.1016 /$ j.nefro.2018.05.010

105. Teatini U, Liebchen A, Nilsson LG, Beck W, Longhena GR. Effect of a more permeable dialysis membrane on ESA resistance in hemodialysis patients--a pilot investigation. Blood Purif. 2016;41(1-3):80-86. DOI: 10.1159/000441437

106. Erlingmark J, Hedstrom M, Lindberg M. Nurse staffing and renal anemia outcomes in haemodialysis care. J Ren Care. 2016;42(3):185-189. DOI: $10.1111 /$ jorc. 12167 